\title{
FENOMENA BERBAGAI SIFAT FISIKA DAN KIMIA TANAH MENDUKUNG KETAHANAN TANAMAN PANGAN DI SUMATERA BARAT
}

\author{
(Various Physical And Soil Chemical Properties Phenomena Support The Food Security \\ In West Sumatera)
}

\author{
Jamilah Munir dan Welly Herman \\ Prodi Agroteknologi, Fakultas Pertanian Unitas Padang \\ jamilahfatika@gmail.com; welly_herman@yahoo.com
}

Article Submitted : 19-02-2019

Article Accepted : 04-04-2019

\begin{abstract}
The objective was to examine the phenomenon of physical and chemical properties of soil which is used as a center of agricultural cultivation in supporting food security in West Sumatra. The experiment was conducted by survey to various locations by taking composite soil samples in the field. Some types of soil taken include Histosol from Anai Padang Pariaman; Ultsiol from Lubuk Minturun; Inceptisol from Limau Manis and Siteba city of Padang; Andisol from Danau Kembar and Lembah gumanti Kab. Solok. The result was can be concluded that Ultisol Lubuk Minturun more potency for tropical fruits. Andisol in Lembah Gumanti and Danau Kembar Kab. Solok has decreased its chemical quality. It is necessary to increase soil $\mathrm{pH}$ to be suitable for the development of vegetable crops and food crops. The use of lime and organic matter in a proper fertilizing package can reduce the use of heavy fertilizer for vegetable crops and horticultura. Histosol utilization for wetland rice cultivation needs to be careful because the acidic $\mathrm{pH}$ and the number of organic acids are toxic. Inceptisol Limau Manis Padang has a neutral $\mathrm{pH}$, and is very good for developing food cultivation in support of food security in West Sumatra.
\end{abstract}

Key words: Ultisol, Inceptisol, Andisol, Histosol, Particel Density

\section{PENDAHULUAN}

Sumatera Barat merupakan suatu bagian daratan yang berada di Pulau Sumatera. Sumatera Barat terletak di pesisir barat bagian tengah pulau Sumatera yang terdiri dari dataran rendah di pantai barat dan dataran tinggi vulkanik yang dibentuk oleh Bukit Barisan. Provinsi ini memiliki daratan seluas $42.297,30 \mathrm{~km}^{2}$ yang setara dengan 2,17\% luas Indonesia. Sebagian besar penduduk yang bekerja terserap di sektor pertanian. Lapangan pekerjaan di sektor ini mampu menyerap $42,4 \%$ dari tenaga kerja yang ada (Pemerintahan Sumatera Barat, 2017); (Cahyono, 2018).
Tanah-tanah di Sumatra Barat cukup bervariasi dan sangat dipengaruhi oleh bahan induk, bahan organik, iklim, topografi dan waktu. Tanah yang dijumpai terdiri dari tanah organik dan tanah mineral. Tanah organik dalam sistim klasifikasi Taksonomi Tanah USDA termasuk ordo Histosol dan mencapai luas 120.900 ha. Nama tanah mineral, menurut sistem Taksonomi Tanah, di daerah ini terdiri dari: (1) Inceptisols dengan luas 2.223.000 ha; (2) Andisols luasnya mencapai 359.200 ha; (3) Ultisols seluas 635.500 ha; (4) Oxisols tersebar sampai $133.600 \mathrm{ha}$; (5) Entisols 111.800 ha dan (6) Alfisols mencapai 64.680 ha (Pemrov Sumbar, 2017).

Tanah Ultisols dan Oxisols tergolong tanah tua dan telah mengalami proses 
pelapukan lanjut, terutama pada tanah yang berasal dari batuan Pretersier dan Tersier, bersolum dalam, tekstur halus, bereaksi masam, miskin unsur hara dan kation basa. Tanah Entisols merupakan tanah muda yang baru terbentuk sedangkan Inceptisols dan Andisols adalah tanah yang lebih berkembang.dibandingkan dengan Entisols. Alfisols tergolong kepada tanah yang telah berkembang dengan sempurna dan mengandung kation basa yang lebih tinggi bila dibandingkan dengan Inceptisos, Ultisols ataupun Oxisols. Dengan demikian Alfisols lebih subur dari tanah jenis lainnya. Kesuburan yang baik dari Alfisols ini disebabkana tanah ini mempunyai bahan induk karst atau batukapur yang kaya akan $\mathrm{Ca}$ dan $\mathrm{Mg}$ sehingga kejenuhan basanya $>35 \%$ (Dwi, 2010).

Beberapa jenis tanah memiliki karakteristik kimia dan fisika yang baik, dan beberapa jenis lainnya bahkan tidak mendukung usaha pertanian yang akan dilakukan, akibat lahan yang suboptimal. Pada kajian ini akan dianalsis beberapa sifat fisika dan kimia tanah pada berbagai jenis tanah dan tempat yang ada di Sumatera barat yang pada lokasi tersebut intensif digunakan sebagai lahan pertanian. Bebarapa tindakan petani yang masih keliru dalam melakukan interpretasi terhadap kualitas tanah yang digunakannya untuk budidaya tanaman pertanian. Petani tidak melakukan analisis tanah ataupun telaahan tanah sehubungan dengan komoditi yang akan dikembangkannya. Oleh sebab itu wajar saja input yang sudah diberikan banyak namun hasil pertanian tidak mencapai produksi yang optimal. Alasannya sederhana, karena mengatasi permasalahannya tidak sesuai dengan diagnosa permasalahnnya. Hingga saat ini permasalah karakteristik tanah belum ditelaah secara optimal. Oleh sebab itu pada laporan berikut ini akan disampaikan kualitas fisika dan kimia tanah $(\mathrm{pH})$ dari berbagai tanah sentra pertanian yang biasa digunakan petani untuk budidaya padi, sayuran dan buah-buahan. Pada kajian ini perlu untuk diketahui apakah tanah yang ada di Sumatera Barat masih memiliki kesuburan yang stabil atau sudah mengalami degradasi baik dari sifat fisika dankimianya. Seperti diketahui bahwa Andisol Di Danau Kembar dan Lembah Gumanti Kabupaten Solok sangat intensif dibudidayakan tanaman sayur dan hortikultura. Masih belum diketahui apakah tanah tersebut masih stabil kesuburannya dalam mendukung ketahanan pangan di Sumatera Barat.

Tujuan penelitian adalah menguji fenomena sifat fisika dn kimia tanah yang dijadikan sentra budidaya pertanian dalam mendukung ketahanan pangan di Sumatera Barat.

\section{METODE PENELITIAN}

Percobaan ini dilakukan dengan survey secara langsung ke berbagai daerah sampling yang ada di Sumatera Barat dimulai bulan Mei hingga Juni 2017. Bahan yang digunakan adalah tanah dengan berbagai jenis diambil dari lokasi pertanian di berbagai daerah di Sumatera Barat, yang sudah diberakan minimal 1 tahun. Alat yang digunakan antara lain; neraca digital ketelitian 3 angka dibelakang koma; oven listrik memmert; $\mathrm{pH}$ elektroda dengan ketelitian pengukuran 2 digit dibelakang koma, eksikator, gelas ukur, gelas piala, pipa kaca, plastik hitam, cawan timbang, shaker, alat-alat tulis.

Metoda percobaan dilakukan dengan analisis deskriptif dari sifat fisika dan kimia tanah yang diambil dari beberapa lokasi di Sumatera Barat di laboratorium Dasar Fakultas Pertanian Unitas Padang. Beberapa jenis tanah antara lain; Histosol; Inceptisol; Ultisol dan Andisol. Pengambilan sampel tanah dilakukan secara komposit dengan menyingkirkan lapisan tanah atas dari tumpukan serasah hingga ke dalaman $20 \mathrm{~cm}$ (Suganda et al, 2005) . Beberapa titik sampel tersebut digabung dalam suatu kantong plastik bersih untuk dibawa ke laboratorium. Sampel tanah kemudian dikering anginkan 
dalam media dederan. Setelah kering, tanah dihaluskan dengan menggunakan lumpang porselin, lalu diayak hingga lolos ayak 80 mesh. Parameter pengamatan antara lain; kadar air tanah kering saat wilting point; kadar air tanah saat kapasitas lapang, partikel density, bulk density, total ruang pori dan $\mathrm{pH}$ tanah.

Pelaksanaan sebagai berikut; sampel tanah masing-masing ditimbang untuk; penetapan kadar air tanah saat titik layu, kadar air tanah kapasitas lapang, bulk densiti, partikel density total ruang pori dan $\mathrm{pH}$ tanah. Cara kerja penetapan kadar air tanah kering udara atau titik layu,dialkukan sebagai berikut; Tanah $10 \mathrm{~g}$ ditimbang kemudian dimasukan ke dalam cawan timbang, dimasukan ke dalam oven suhu $105^{\circ} \mathrm{C}$, selama 2 hari atau sampai beratnya tetap. Selanjutnya tanah yang sudah dikeringkan dioven disejukkan dalam eksikator selama beberapa menit kemudian ditimbang untuk mendapatkan berat kering oven rumus penetapan kadar air tanah kering saat titiklayu $\mathrm{KA}=(\mathrm{BA}-\mathrm{BKO}) / \mathrm{BKO} \times 100 \%$. Keterangan; $\mathrm{KA}=$ kadar air; $\mathrm{BA}=$ berat awal; $\mathrm{BKO}=$ berat kering oven. Penetapan kadar air tanah saat kapasitas lapang dilaksanakan sebagai berikut; disiapkan gelas piala volume $1000 \mathrm{~mL}$. Isi pasir kering kira-kira $1 / 4$ bagian gelas. Selanjutnya tegakkan pipa kaca ditengahnya tepat di atas permukaan lapisan pasir tersebut, kemudian masukkan tanah halus sampel hingga $3 / 4$ tinggi gelas. Selanjutnya ratakan permukaan, lalu disiram air hingga permukaan tergenang, dan biarkan air merembes ke dalam lapisan tanah. Gelas piala ditutup plastik hitam dan dibiarkan tanah tersebut 1 malam, agar air bebar-benar merembes ke lapisan pasir. Pekerjaan selanjutnya mengambil tanah lembab pada kondisi saat kadar air kapasitas lapang di bagian tengah gelas, sebanyak $10 \mathrm{~g}$. Pekerjaan penetapannya sama seperti penetapan kadar air kering udara atau wilting point. Penetapan Bulk Density, Partikel Density dan Total Ruang Pori sebagai berikut; Ambil tanah kering udara yang telah dihaluskan masukkan ke dalam gelas ukur hingga batas $55 \mathrm{ml}$. Lalu ketuk-ketuk selama 15 menit atau hingga permukaan tanah di dalam gelas tidak turun lagi. Lalu catat volume tanah terakhir tersebut sebagai VT. Kemudian timbang tanah tersebut (BA). Bulk density $=$ berat/volume $(\mathrm{g} / \mathrm{cm} 3)$ atau $\mathrm{g} / \mathrm{ml}$ atau BA/VT. Gelas ukur diisi air hingga $70 \mathrm{~mL}$. Lalu secara perlahan tuangkan tanah yang telah ditimbang tadi ke dalam gelas ukur tersebut. Kemudian aduk hingga semua udara keluar. Kemudian dicatat volume air dan tanah tersebut. Volume ruang pori $=(\mathrm{Vol}$ air + VT) $-($ Vol air+tanah). Total ruang pori $=$ vol.ruang pori/vol.tanah $\times 100 \%$. Partikel Densiti $=$ berat tanah/(volume tnh-Vol. ruang pori) $\left(\mathrm{g} / \mathrm{cm}^{3}\right)$ (Hanafiah, 2005).

Penetapan $\mathrm{pH}$ tanah dilakukan dengan menimbang tanah kering $10 \mathrm{~g}$, lalu dimasukkan ke dalam botol kocok, diisi air aquabidestilasi seanyak $25 \mathrm{ml}$, kemudian dikocok selama 20 menit, dan dibiarkan hingga mengendap lalu diukur $\mathrm{pH}$ dengan alat pH meter elektroda (Sarief. 1990).

\section{HASIL DAN PEMBAHASAN}

Berdasarkan sifat fisik dan kimia tanah dibedakan berdasarkan jenis tanahnya. Secara umum berdasarkan bahan induknya tanah digolongkan atas 2 yaitu tanah mineral dan tanah organik. Tanah mineral terbentuk dari hasil perkembangan (genesa) dari bahan induk yang terbentuk dari hasil pelapukan (weathering) batuan. Tanah organik (gambut) atau Histosol terbentuk dari bahan induk organik hasil pelapukan secara anaerob bahan organik. Ternyata kedua golongan tanah tersebut berbeda sifat fisik dan kimia $(\mathrm{pH})$, disajikan pada Tabel 1 dan 2. 
Tabel 1. Berat Volume, partikel density dan total ruang pori berdasarkan jenis tanah di Sumatera Barat

\begin{tabular}{llccc}
\hline No & Jenis Tanah & BD & PD & $\begin{array}{c}\text { TRP } \\
(\%)\end{array}$ \\
\hline 1 & $\begin{array}{l}\text { Gambut (Histosol) } \\
\text { Padang Pariaman }\end{array}$ & 0,65 & 1,48 & 55,00 \\
2 & $\begin{array}{l}\text { Podsolik Merah Kuning } \\
\text { (Ultisol) Lubuk Minturun }\end{array}$ & 1,21 & 2,26 & 46,51 \\
3 & $\begin{array}{l}\text { Alluvial Limau Manis } \\
\text { (Inceptisol) }\end{array}$ & 1,19 & 2,07 & 42,31 \\
4 & $\begin{array}{l}\text { Alluvial Siteba (Inceptisol) } \\
5\end{array}$ & 1,13 & 2,21 & 50,00 \\
Andisol (Danau Kembar & 0,84 & 1,44 & 42,00 \\
6 & $\begin{array}{l}\text { Solok) Andisol (Lembah Gumanti, } \\
\text { Solok) }\end{array}$ & 0,74 & 1,54 & 52,00 \\
\hline
\end{tabular}

Sumber: Hasil analisis di laboratorium dasar Prodi Agroteknologi, FP Unitas, Padang, 2018

Ket: BD (bulk density); PD (particle density); TRP (total ruang pori)

Pada Tabel 1, dapat dijelaskan bahwa bulk density (BD) atau kerapatan lindak tanah khusus Histosol sebesar $0,65 \mathrm{~g} \mathrm{~cm}^{-3}$, Andisol mencapai $0,79 \mathrm{~g} \mathrm{~cm}^{-3}$ sedangkan tanah mineral yang tergolong Ultisol danAlluvial (Inceptisol) berkisar 1,13-1,19 g $\mathrm{cm}^{-3}$. Laporan penelitian (Prasetya, Prijono, \& Widjiawati, 2012) juga membuktikan bahwa BD Andisol Ngabab, Kecamatan Pujon sebesar 0,64- $0,82 \mathrm{~g} \mathrm{~cm}^{-3}$. Selanjutnya BD sebesar $0,75 \mathrm{~g} \mathrm{~cm}^{-3}$ pada Andisol Lembang (Sumarni dan Rosliani, 2010). Bulk density suatu tanah menunjukkan kepadatan alami tanah tersebut dalam kondisi undisturbed (tidak terganggu). Jika angka BD semakin kecil, menujukkan bahwa tanah secara alami semakin berpori atau gembur, demikian sebaliknya jika BD semakin besar, menunjukkan bahwa secara alami tanah cenderung padat. Bulk density tanah Ultisol Lubuk Minturun tertinggi dibandingkan dengan jenis tanah lainnya, menunjukkan tanah tersebut lebih didominasi partikel liat, sehingga dapat menghambat drainase tanah dan penetrasi akar ke dalam tanah.

Total ruang pori Alluvial Limau Manis dan Andisol Danau Kembar paling rendah dibandingkan semua jenis tanah yang diuji. Hal ini membuktikan bahwa tanah didominasi oleh mineral berfraksi kasar menghambat terbentuknya ruang pori mikro. Total ruang pori yang terbatas akan menghambat ketersediaan udara dan air bagi tanaman yang tumbuh, karena total ruang pori merupakan penjumlahan pori makro tempat udara dan pori mikro tempat air tersedia. Total ruang pori tanah yang ideal berkisar $50 \%$, yang berisi $\pm 25 \%$ mengandung udara di pori makro dan $\pm 25 \%$ mengandung air berada di pori mikro atau kapiler. Tanah gambut (histosol) secara umum memang memiliki pori yang sangat banyak atau bersifat poreous. Hal ini menyebabkan jika tanah tersebut dalam keadaan drainase yang baik, maka tanah tidak tergenang. Menurut (Weil \& Brady, 2016) sifat pengatusan (drain) yang baik, memudahkan udara masuk dalam pori makro, yang berguna untuk respirasi akar dan penetrasi perakaran sehingga jangkauan serapan hara dan air menjadi tambah luas. Pada tanah mineral total ruang pori Inceptisol Siteba lebih baik dan sangat ideal sebagai media tumbuh tanaman. Total ruang pori tanah gambut (Ultisol) sangat tinggi, dapat mengakibatkan tanaman kesulitan tumbuh tegak. Keuntungan dari sisi lainnya adalah 
tanah lebih aerasi dan lingkungan fisik sangat sesuai untuk kebutuhan tanaman.

Partikel density adalah berat tanah berdasarkan volume padatannya saja. Angkanya harus lebih tinggi dibandingkan nilai bulk density, karena semua pori sudah dikeluarkan. Nilai Partikel density yang semakin besar terhadap nilai bulk density, maka kandungan ruang pori di dalam tanah juga menjadi besar. Demikian juga sebaliknya jika angka PD tetap akan tetapi nilai BD makin besar, maka dipastikan total pori tanah semakin sedikit (Anonim, 2015). Secara umum tanah Ultisol dan Inceptisol di Sumatera Barat $\mathrm{BD}>2 \mathrm{~g} \mathrm{~cm}^{-3}$, hal ini menunjukkan bahwa kandungan mineral kasar tanah tersebut sangat tinggi, sedangkan tanah Andisol dan Histosol memiliki PD $<2$ $\mathrm{g} \mathrm{cm}^{-3}$ disebabkan tanah tersebut masih cukup tinggi kadar bahan organiknya.

Total ruang pori (TRP) berikisar 50 55\% hanya dimiliki oleh tanah Histosol Padang Pariaman, Andisol Lembah Gumanti dan Inceptisol Siteba Kota Padang, dan selebihnya TRP $<50 \%$. Total ruang pori yang tinggi menunjukkan bahwa aerasi tanah cukup tinggi tanah cukup rongga menyediakan oksigen. Menurut (Widjaya Adhi, 1988) bahwa TRP Histosol bisa mencapai 95\%. Secara umum sifat Andisol adalah lebih berongga, akan tetapi kalau dilihat pada Tabel 1, Andisol Danau Kembar sudah mengalami kepadatan. Makanya tidak heran petani bawang di sana sering mendatangkan pupuk kandang dlam jumlah banyak salah satu disebabkan tanahnya sudah mulai padat. Bahkan angka TRPnya menyamai Ultisol Lubuk Minturun yang tergolong tanah sub optimal.

Hubungan antara ruang pori dan sifat menahan air tanah yang ditahan oleh pori mikro dalam pipa kapiler tanah, disajikan pada Tabel 2. Tanah Histosol mampu menahan air pada pori mikronya hingga $116 \%$, melebihi bobot partikelnya. Keunggulan Histosol karena kandungan koloid humusnya yang tinggi, sehingga pori mikro menjadi sangat banyak.

Tabel 2. Kadar air tanah saat kering udara dan kapasitas lapangdan $\mathrm{pH}$ berdasarkan jenis tanah di Sumatera Barat

\begin{tabular}{|c|c|c|c|c|}
\hline \multirow{2}{*}{ No } & \multirow{2}{*}{ Jenis Tanah } & \multicolumn{2}{|c|}{ Kadar Air Tanah (\%) } & \multirow{2}{*}{ pH Tanah* } \\
\hline & & Wilting point & Kapasitas Lapang & \\
\hline 1 & $\begin{array}{l}\text { Gambut (Histosol) Anai Padang } \\
\text { Pariaman }\end{array}$ & 32,50 & 116,00 & $4,60 \mathrm{~m}$ \\
\hline 2 & $\begin{array}{l}\text { Podsolik Merah Kuning } \\
\text { (Ultisol) Lubuk Minturun }\end{array}$ & 3,51 & 60,51 & $4,82 \mathrm{~m}$ \\
\hline 3 & $\begin{array}{lll}\text { Alluvial } & \text { Limau } & \text { Manis } \\
\text { (Inceptisol) } & & \end{array}$ & 7,29 & 39,80 & $7,56 \mathrm{n}$ \\
\hline 4 & Alluvial Siteba (Inceptisol) & 8,81 & 50,00 & $5,47 \mathrm{~m}$ \\
\hline 5 & Andisol (Danau Kembar, Solok) & 29,33 & 47,25 & $4,26 \mathrm{sm}$ \\
\hline 6 & $\begin{array}{l}\text { Andisol (Lembah Gumanti, } \\
\text { Solok) }\end{array}$ & 35,87 & 47,80 & $4,35 \mathrm{sm}$ \\
\hline
\end{tabular}

Sumber: Hasil analisis di laboratorium dasar Prodi Agroteknologi, FP Unitas, Padang, 2018

*) keterangan $\mathrm{m}=$ masam; $\mathrm{sm}=$ sangat masam dan $\mathrm{n}=$ netral (Azzami, 2016)

Pori mikro berperan tempat menyimpan air sebagai air tersedia. Peranan koloid lainnya yang bersifat menyimpan air adalah liat. Secara umum Ultisol memiliki kandungan liat yang juga cukup tinggi dibandingkan tanah Alluvial. Oleh sebab itu dalam kondisi kelembaban kapasitas lapang Ultisol mampu menahan air 52\% lebih tinggi dibandingkan Alluvial Limau Manis. Sudah dapat diduga kadar mineral liat Alluvial jauh 
lebih rendah dibandingkan kadar liat Ultisol. Alluvial tergolong tanah Inceptisol yang baru berkembang, sedangkan Ultisol tergolong tanah tua, yang dicirikan dengan tingginya kandungan mineral halus yang bersifat koloid.

Kadar air tanah saat titik layu (wilting point) juga berbeda antara Histosol dan tanah mineral (Ultisol dan Inceptisol). Air tanah yang terikat pada kondisi titik layu (wilting point) sudah sangat terikat kuat oleh partikel tanah, sehingga sukar akar tanaman mendapatkannya. Kondisi kadar air saat wilting point pada ke 2 Alluvial tersebut angkanya hampir sama berkisar 7-8,8\%, sedangkan Ultisol Lubuk Minturun hanya $3,5 \%$. Ternyata tidak selamanya kalau kadar air saat kapasitas lapang yang tinggi akan juga memberikan gambaran kadar air saat kondisi wilting point juga tinggi kadar air tanahnya. Wilting point Histosol dan Andisol masih cukup tinggi berkisar 29-32 \%, hal ini menunjukkan bahwa walaupun kondisi tanah sudah kering namun kemampuan tanah mengikat air cukup tinggi. Hal ini tidak lepas dari tingginya kandungan bahan organik pada tanah tersebut. Bahan organik tanah memiliki pori yang cukup besar sehingga mampu menyimpan air walaupun tanah dalam kondisi kering.

Reaksi kimia tanah (pH) tanah terendah dijumpai pada Histosol. Keasaman yang tinggi yang diakibatkan tingginya asam organik tanah Histosol banyak menyumbangkan ion $\mathrm{H}^{+}$. Tanah mineral yang tergolong asam pada Tabel 2 adalah Ultisol Lubuk Minturun. Keasaman tanah mineral banyak disebabkan oleh kelarutan ion $\mathrm{H}^{+}$dan $\mathrm{Al}^{3+}$ yang tinggi. Ada 3 jenis tanah yang memiliki $\mathrm{pH}<5$, yaitu Histosol, Ultisol dan Andisol. Sangat wajar kalau Histosol Padang pariaman bereaksi asam, karena tanah tersebut banyak mengandung asamasam organik yang larut. Asam tersebut banyak menyumbangkan ion $\mathrm{H}$ sehingga mengakibatkan $\mathrm{pH}$ rendah. Asam organik memberikan kontribusi nyata terhadap rendahnya $\mathrm{pH}$ tanah gambut (Charman,
2002) (Sagiman, 2007). Kemasaman tanah gambut tropika umumnya tinggi $(\mathrm{pH} 3-5)$, disebabkan oleh buruknya kondisi pengatusan dan hidrolisis asam-asam organik, yang didominasi oleh asam fulvat dan humat (Widjaja-Adhi, 1988; Rachim, 1995). Bahan organik yang telah terdekomposisi mempunyai gugus reaktif, antara lain: karboksilat (-COOH) dan fenolat $(\mathrm{C} 6 \mathrm{H} 4 \mathrm{OH})$ yang mendominasi kompleks pertukaran dan bersifat sebagai asam lemah sehingga dapat terdisosiasi dan menghasilkan ion $\mathrm{H}$ dalam jumlah banyak. Kemasaman tanah yang tinggi mempengaruhi ketersediaan unsur hara seperti $\mathrm{P}, \mathrm{K}, \mathrm{Ca}$, dan unsur mikro (Marschner, 1986). Gambut mentah (fibrik) yang belum terurai mengandung kadar asam-asam organik lebih tinggi, sedangkan gambut saprik umumnya mengandung abu yang lebih banyak sebagai sumber basa-basa (Masganti, 2003; Kurnain et al., 2005) (Sagiman, 2007).

Tanah Andisol dari Lembah Gumanti danDanau Kembar sama-sama tergolong sangat masam. Kemasaman tanah sangat mempengaruhi pertumbuhan tanaman pangan dan sayuran. Menurut (Ariyanto, 2012) pemberian pupuk harus memperhatikan reaksi kimia tanah. Jika tanah sangat masam, maka pemberian pupuk akan sangat tidak efektif. Menururt (Bradley \& Hosier, 1999) kemasaman tanah akan mengakibatkan tanaman; menyebabkan penurunan ketersediaan unsur hara bagi tanaman; Meningkatkan dampak unsur Fe dan Al beracun dalam tanah; Penurunan produktifitas tanaman; menghambat serapan unsur $\mathrm{Ca}, \mathrm{Mo}, \mathrm{Mg}$ dan N. Akibatnya produksi rendah dan sering berkembang gangguan fisiologi akibat hama dan penyakit tanaman.

Tindakan pemupukan berat hampir $900 \mathrm{~kg} \mathrm{ha}^{-1}$ pupuk majemuk seperti yang sudah dilakukan pada tanaman bawang di Andisol Lembah Gumanti, bisa dihindarkan apabila kemasaman tanah $\mathrm{pH}$ tanah dilakukan recovery. Akibat pemberian pupuk berat mengakibatkan tanaman rentan terhadap gangguan hama dan penyakit. Hal ini 
dibuktikan bahwa petani bawang di Lembah Gumanti menyemprot racun pengendali hama dan penyakit hingga 30 kali sampai bawang dipanen (Milda et al, 2016). Hal ini sudah sangat mencemari lingkungan. Padahal diketahui kebutuhan hidup bawang merah, cabe merah serta sayur mayur pada umumnya membutuhkan $\mathrm{pH}$ berkisar 5,6-6,5 (BPPP Kementrian Pertanian, 2015). Oleh sebab itu perlu ada penambahan kapur dan bahan organik sehingga dapat mengurangi penggunaan pupuk yang berat untuk tanaman bawang dan sayur lainnya. Selain tanaman dan lingkungan lebih sehat juga menghemat ongkos usaha tani.

\section{KESIMPULAN}

Ultisol Lubuk Minturun lebih potensial dikembangan tanaman buah-buhan tropika. Tanah Andisol Lembah Gumanti dan Danau Kembar Kab. Solok sudah menurun kualitas kimianya, akan tetapi tidak begitu buruk kualitas sifat fisikanya. Perlu upaya peningkatan $\mathrm{pH}$ tanah agar sesuai untuk pengembangan tanaman sayuran dan tanaman pangan. Penggunaan kapur dan bahan organik dalam suatu paket pemupukan yang tepat dapat mengurangi penggunaan pupuk berat untuk tanaman sayuran dan hortikultura. Pemanfaatan Histosol untuk budidaya padi sawah perlu kehati-hatian karena $\mathrm{pH}$ yang asam dan banyaknya asam organik bersifat racun. Inceptisol Limau Manis Padang memiliki $\mathrm{pH}$ yang netral, dan sangat baik untuk dikembangkan budidaya tanaman pangan dalam mendukung ketahanan pangan di Sumatera Barat.

\section{UCAPAN TERIMA KASIH}

Ucapan terima kasih disampaikan kepada Mahasiswa Program Studi Agroteknologi yang telah ikut berpartisipasi mulai dari pengambilan sampel tanah di lapangan, penetapan sifat-sifat fisika dan kimia tanah di Laboratorium hingga pengambilan data. Ucapan terima kasih juga disampaikan pada Fakultas Pertanian yang telah mendanai kegiatan ini.

\section{DAFTAR PUSTAKA}

Azzami. 2016. Karakteristik Tanah Masam dan Cara Menaikkan pH Tanah Masam. Mitalocom.

https://mitalom.com/karakteristiktanah-masam-dan-cara-menaikkan-phtanah-masam/. Diakses 17 Juli 2018.

Anonim. 2015. Peranan bahan organik terhadap kesuburan tanah. Statewide Agricultural Land Use Baseline 2015, 1.

Bradley, L., \& Hosier, S. 1999. Guide to Symptoms of Plant Nutrient Deficiencies. The University of Arizona Cooperative Extension, AZ1106, 1-3.

Cahyono, S. 2018. Pemprov Sumbar Kebut Penuntasan Batas Wilayah. https://www. jawa pos.com/jpgtoday/26/03/2018/pemprov-sumbarkebut-penuntasan-batas-wilayah

Charman, D. 2002. Peatlands and Environmental Change. John Wiley \& Sons. Ltd. England.

Dwi Ikhwan. 2010. Kondisi Tanah Pulau Sumatera. I-geografy. http://onegeo.blogspot.com/2010/01/kondisi-tanahpulau-sumatera.html, akses, 15 Juli 2018.

Hanafiah. 2005. Dasar-dasar Ilmu Tanah Penerbit PT Mediatama Sarana Perkasa.

Sarief, S. 1990. Dasar-dasar Ilmu Tanah, Armico Bandung.

Marschner, H. 1986. Mineral Nutrition of Hogher Plants. Acc Press. Harcourt Jovanovich Publishers. London, San Diego, New York, Berkeley, Boston, Sydney, Tokyo, Toronto. 673 p. 
Masganti. 2003. Kajian Upaya Meningkatkan Daya Penyediaan Fosfat dalam Gambut Oligotrofik. Disertasi. Program Pascasarjana Universitas Gadjah Mada. Yogyakarta. 350 hal.

Milda, E. Z. J. 2016. Aplikasi Rizobakteri Dalam Meningkatkan. JPKM, 22(3), 131-134.

Pemerintahan Sumatera Barat. 2017. Adiminstrasi Pemerintahan. https://www.sumbarprov.go.id/detail s/category/80. Akses 16 Juli 2018.

Pemprov Sumbar. 2017. Sumatera Barat. http://www.sumbarprov.go.id/ details/news/340. Diakses 16 Juli 2018.

Prasetya, B., Prijono, S., \& Widjiawati, Y. 2012. Vegetasi Pohon Hutan Memperbaiki Kualitas Tanah Andisol-Ngabab. Indonesian Green Technology Journal, 1(1), 1-6.

Pusat Penelitian dan Pengembangan hortikultura. 2015. Budidaya Bawang Merah. Badan Penelitian dan Pengembangan Pertanian, Kementrian Pertanian.

Rachim A. 1995. Penggunaan Kation-Kation Polivalen dalam Kaitannya dengan
Ketersediaan Fosfat untuk Meningkatkan Produksi Jagung pada Tanah Gambut. Disertasi. Program Pascasarjana IPB. Bogor. 268 hal.

Sagiman, S. 2007. Pemanfaatan lahan gambut dengan perspektif pertanian berkelanjutan. Orasi Ilmiah Pengukuhan Guru Besar, UNTAN, Pontianak.

Sumarni; Rosliani, R. A. S. D. 2010. Pengelolaan Fisik, Kimia, dan Biologi Tanah untuk Meningkatkan Kesuburan Lahan dan Hasil Cabai Merah. J. Hort, 20(2), 130-137.

Suganda, Husein; Achmad Rachman dan Sutono. 2005. Petunjuk Pengambilan Contoh Tanah. http://balittanah.litbang.pertanian.go. id/ind/dokumentasi/buku/buku\%20si fat $\% 20 \quad$ fisik $\% 20$ tanah /02petunjuk_contoh_tanah.pdf?secur $\mathrm{e}=$ true. Diakses tanggal $17 \mathrm{Juli} 2018$.

Weil, R. R., \& C.Brady, Ny. 2016. the Nature and Properties of Soils. 15th edition. Constraints (Fifteenth). Macmillan: Macmillan Publishing Company. 